\title{
Identification of a $\beta$ Subunit TM2 Residue Mediating Proton Modulation of GABA Type A Receptors
}

\author{
Megan E. Wilkins, Alastair M. Hosie, and Trevor G. Smart \\ School of Pharmacy, Department of Pharmacology, University of London, London, WC1N 1AX, United Kingdom
}

\begin{abstract}
GABA type $A\left(G A B A_{A}\right)$ receptors are functionally regulated by external protons in a manner dependent on the receptor subunit composition. Although $\mathrm{H}^{+}$can regulate the open probability of single GABA ion channels, exactly what residues and receptor subunits are responsible for proton-induced modulation remain unknown. This study resolves this issue by using recombinant $\alpha 1 \beta \mathrm{i}$ subunit $\mathrm{GABA}_{\mathrm{A}}$ receptors expressed in human embryonic kidney cells. The potentiating effect of low external $\mathrm{pH}$ on GABA responses exhibited $\mathrm{p}_{\mathrm{Ka}}$ in accord with the involvement of histidine and/or cysteine residues. The exposure of $\mathrm{GABA}_{\mathrm{A}}$ receptors to the histidine-modifying reagent DEPC ablated regulation by $\mathrm{H}^{+}$, implicating the involvement of histidine residues rather than cysteines in proton regulation. Site-specific substitution of all conserved external histidines to
\end{abstract}

GABA type $A\left(\mathrm{GABA}_{\mathrm{A}}\right)$ receptors are the major mediators of inhibitory neurotransmission in the brain. Fast inhibition occurs via the synaptic $\mathrm{GABA}_{\mathrm{A}}$ receptors (Smart, 1998), whereas extrasynaptic isoforms have been demonstrated to underlay continuous tonic inhibition (Otis et al., 1991). Those receptors expressed at inhibitory synapses will be regulated by endogenous processes, including trafficking, endocytosis, phosphorylation, redox reagents, and ions normally present in vivo (e.g., $\mathrm{Zn}^{2+}$ and $\mathrm{H}^{+}$) (Kaila, 1994; Sieghart, 1995; Rabow et al., 1996; Moss and Smart, 2001). Variations in the level of endogenous ions in the CNS represent a rapid and effective method for regulating receptor function (Kaila, 1994; Smart et al., 1994). Previous studies have indicated that protons can differentially affect neuronal $\mathrm{GABA}_{\mathrm{A}}$ receptors, resulting in potentiation, inhibition, or no effect on GABA-activated responses (Kaila, 1994; Robello et al., 1994; Pasternack et al., 1996; Zhai et al., 1998; Krishek and Smart, 2001). This variability to $\mathrm{pH}$ has been ascribed to differences in the neuronal receptor subunit composition that can be reproduced to some extent using recombinant $\mathrm{GABA}_{\mathrm{A}}$ receptors (Krishek et al., 1996).

$\mathrm{GABA}_{\mathrm{A}}$ receptors are presumed to be pentameric proteins (Nayeem et al., 1994) composed of combinations of the following subunits: $\alpha(1-6), \beta(1-3), \gamma(1-3), \delta, \epsilon, \pi$, and $\theta$ (Rabow et al., 1996; Mehta and Ticku, 1999). Notably, receptors composed of $\alpha 1 \beta 1, \alpha 1 \beta 1 \delta$, and $\alpha 1 \beta 1 \gamma 2 \delta$ subunits were differentially sensitive to external $\mathrm{pH}$, whereas the $\alpha 1 \beta \mathrm{i} \gamma 2$ subunit combinations (where

\footnotetext{
Received Jan. 31, 2002; revised April 18, 2002; accepted April 18, 2002.

This work was supported by the Medical Research Council. We thank Robert Harvey for providing $\beta 1 / 2^{\mathrm{H} 267 \mathrm{~A}}$ clones.

Correspondence should be addressed to T. G. Smart, Department of Pharmacology, University College London, WC1E 6BT, UK. E-mail: t.smart@ucl.ac.uk.

M. E. Wilkin's and A. M. Hosie's present address: Department of Pharmacology, University College London, London, WC1E 6BT, UK.

Copyright (C) 2002 Society for Neuroscience $\quad 0270-6474 / 02 / 225328-06 \$ 15.00 / 0$
}

alanine on the $\beta$ subunits revealed that $\mathrm{H} 267$ alone, in the TM2 domain, is important for $\mathrm{H}^{+}$regulation. These results are interpreted as a direct protonation of $\mathrm{H} 267$ on $\alpha 1 \beta$ i receptors rather than an involvement in signal transduction. The opposing functional effects induced by $\mathrm{Zn}^{2+}$ and $\mathrm{H}^{+}$at this single histidine residue most likely reflect differences in charge delocalization on the imidazole rings in the mouth of the $\mathrm{GABA}_{\mathrm{A}}$ receptor ion channel. Additional substitutions of $\mathrm{H} 267$ in $\beta$ subunits with other residues possessing charged side chains (glutamate and lysine) reveal that this area of the ion channel can profoundly influence the functional properties of $\mathrm{GABA}_{A}$ receptors.

Key words: $G A B A_{A}$ receptor; $p H$ modulation; $\beta$ subunit; histidine, $\mathrm{H}^{+}$; ion channel $i=1,2)$ were primarily unaffected (Krishek et al., 1996). Subsequent single-channel studies in neurons indicated that raised $\mathrm{H}^{+}$ concentrations caused inhibition of GABA-activated responses by reducing the single-channel open probability with no effect on channel conductance (Huang and Dillon, 1999; Krishek and Smart, 2001). Furthermore, for cerebellar granule neurons, developmental changes in $\mathrm{GABA}_{\mathrm{A}}$ receptor $\alpha 1$ and $\alpha 6$ subunit expression (Laurie et al., 1992) occurred concurrently with changes in $\mathrm{GABA}_{\mathrm{A}}$ receptor sensitivity to external $\mathrm{pH}$, suggesting that protons may be a useful probe for detecting changes in receptor subunit composition (Krishek and Smart, 2001).

Modulating $\mathrm{GABA}_{\mathrm{A}}$ receptor function with external $\mathrm{pH}$ may be important during CNS trauma and neurological pathologies by causing changes in neuronal excitability (Xiong and Stringer, 2000). However, the underlying amino acid residues on $\mathrm{GABA}_{\mathrm{A}}$ receptors that are responsible for the proton effects remain unidentified. The present study investigates this question using heterologous expression of $\mathrm{GABA}_{\mathrm{A}}$ receptors and resolves that a histidine residue at position 267 in the ion channel domain of the $\beta$ subunit is not only completely responsible for proton regulation of $\alpha 1 \beta \mathrm{i}$ receptor function, but also that after substitution, this location in the ion channel can profoundly influence the functional properties of the $\mathrm{GABA}_{\mathrm{A}}$ receptor. To date, this histidine residue plays a unique role in the function of the $\mathrm{GABA}_{\mathrm{A}}$ receptor's forming a potential ion binding site and significant transduction pathway. Some of these results have been reported previously in abstract form (Wilkins et al., 2001).

\section{MATERIALS AND METHODS}

cDNA constructs and site-specific mutagenesis. The murine $\mathrm{GABA}_{\mathrm{A}}$ receptor $\alpha 1, \beta 1$, and $\beta 2$ subunit cDNAs were cloned into the vector pRK5. Site-specific mutagenesis was achieved by using oligonucleotides in conjunction with a primer-directed PCR method (Quickchange; Stratagene, La Jolla, CA), and purified DNAs were prepared using the Plasmid Maxi 
Kit (Qiagen, Crawley, UK). The entire coding region of all mutants was sequenced using the BigDye ready reaction mix (PerkinElmer Life Sciences, Emeryville, CA/Applied Biosystems, Foster City, CA) and an ABI 310 automated DNA sequencer (Applied Biosystems).

Cell culture and electroporation. Human embryonic kidney (HEK) cells were cultured as described previously (Wooltorton et al., 1997b). The cells were transfected by electroporation (Gene Electropulser II, Hemel Hempstead, UK) using the following parameters: $0.4 \mathrm{kV}, 125 \mu \mathrm{F}$ capacitance, and infinite resistance in the presence of $12 \mu \mathrm{g}$ of cDNA for the $\mathrm{GABA}_{\mathrm{A}}$ receptor subunits, present in equal ratios, and $3 \mu \mathrm{g}$ of green fluorescent protein. Electroporated cells were plated onto poly-L-lysinecoated glass coverslips, which were used for electrophysiological recording 18-72 hr after transfection.

Patch-clamp electrophysiology. Membrane currents were recorded using a whole-cell patch-clamp technique from single HEK cells with an Axopatch 1-C amplifier (Axon Instruments, Foster City, CA). Patch pipettes (resistance, 3-5 M $\Omega$ ) were filled with a solution containing (in mM): $120 \mathrm{KCl}, 1 \mathrm{MgCl}_{2}, 11$ EGTA, $30 \mathrm{KOH}, 10 \mathrm{HEPES}, 1 \mathrm{CaCl}_{2}, 2$ adenosine triphosphate, and 12 creatine phosphate, $\mathrm{pH}$ 7.11. The cells were continuously perfused with Krebs' solution containing (in $\mathrm{mM}$ ): 140 $\mathrm{NaCl}, 4.7 \mathrm{KCl}, 1.2 \mathrm{MgCl}_{2}, 2.52 \mathrm{CaCl}_{2}, 11$ glucose, and either $5 \mathrm{HEPES}$ or 5 MES (see $\mathrm{pH}$ buffers). The Krebs' $\mathrm{pH}$ was finally adjusted to $\mathrm{pH}$ $5.4-8.4$ with 1 or $5 \mathrm{~N} \mathrm{NaOH}$. Membrane currents were filtered at $5 \mathrm{kHz}$ ( $-3 \mathrm{~dB}$, sixth pole Bessel, $36 \mathrm{~dB} /$ octave) and analyzed with Clampex 8 (Axon Instruments). Any change of $>10 \%$ in the membrane conductance/series resistance resulted in the cessation of recording. Drugs and solutions were rapidly applied to the cells using a modified Y-tube positioned $\sim 300 \mu \mathrm{m}$ from the recorded cell. The response rise times were within 20-30 msec (Wooltorton et al., 1997b). All drugs were dissolved in external Krebs' solution at the appropriate $\mathrm{pH}$. DEPC was added directly to the Krebs' solution, immediately before use, to yield final concentrations of $1 \mathrm{~mm}$.

pH buffers. To ensure accurate control of the Krebs' $\mathrm{pH}$ over the range 5.4-8.4, two different $\mathrm{pH}$ buffers were used. For $\mathrm{pH}$ excursions between 6.8 and 8.4, HEPES ( $\mathrm{p}_{\mathrm{Ka}}$ 7.5) was added to the Krebs' solution, and for the $\mathrm{pH}$ range $5.4-7$, MES was used $\left(\mathrm{p}_{\mathrm{Ka}} 6.1\right)$, both at $5 \mathrm{~mm}$ final concentrations.

Analysis of whole-cell current data. Peak amplitude membrane currents activated by GABA $(I)$ were determined at $-50 \mathrm{mV}$ holding potential. GABA equilibrium concentration-response relationships were constructed by measuring the peak GABA currents, which were normalized to the response induced by $10 \mu \mathrm{M}$ GABA in control Krebs' solution at $\mathrm{pH}$ $7.4\left(I_{10}\right)$ and subsequently fitted with the Hill equation:

$$
I / I_{10}=\left[1 / 1+\left(\mathrm{EC}_{50} /[\mathrm{A}]\right)^{n}\right],
$$

where $\mathrm{EC}_{50}$ represents the concentration of GABA ([A]) inducing 50\% of the maximal current evoked by a saturating concentration of GABA and $n$ is the Hill coefficient.

When the maxima of the curves demonstrated a clear depression with incrementing GABA concentration, the data were fitted with the following equation, accounting for the reduced maximum response by assuming that the ligand binds to two distinct sites, one producing potentiation and the other producing inhibition (or desensitization) of the GABAactivated current:

$$
I / I_{10}=\left[1 /\left(1+\left(\mathrm{EC}_{50} / \mathrm{A}\right)^{n}\right)\right]-\left[1 /\left(1+\left(\mathrm{IC}_{50} / \mathrm{A}\right)^{m}\right)\right],
$$

where $I, I_{10}, \mathrm{EC}_{50}$, and $n$ are as defined, $\mathrm{IC}_{50}$ is the GABA concentration producing a $50 \%$ inhibition of the current, and $m$ represents the corresponding Hill coefficient. To ensure a fit to the inhibitory component, occasionally the $\mathrm{IC}_{50}$ was constrained where limited numbers of data points were available.

The GABA concentration-response curve data were analyzed using ANOVA with a Bonferroni post hoc test. Significance was determined at the $p<0.05$ level.

The $\mathrm{Zn}^{2+}$ inhibition concentration relationships were fitted with the following equation:

$$
I_{\mathrm{N}}^{\prime} / I_{\mathrm{N}}=\left[1-\left(B^{n}{ }_{\mathrm{H}} /\left(B^{n}{ }_{\mathrm{H}}+\mathrm{IC}_{50}{ }^{n}\right)\right)\right]
$$

where $I_{\mathrm{N}}{ }^{\prime}$ and $I_{\mathrm{N}}$ represent the normalized GABA-induced current in the presence and absence of $\mathrm{Zn}^{2+}$ at concentration $B$, respectively, and $\mathrm{IC}_{50}$ defines the concentration of $\mathrm{Zn}^{2+}$ producing $50 \%$ inhibition of the GABA-induced current.

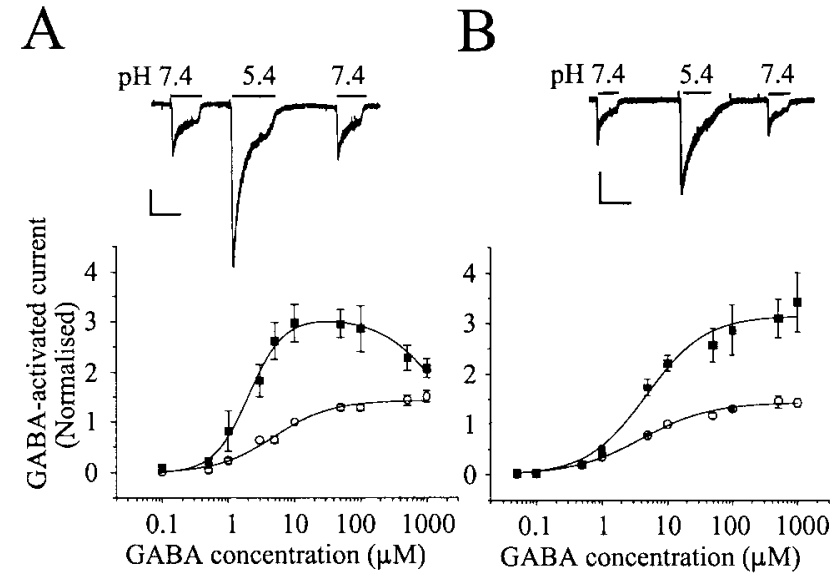

Figure 1. External $\mathrm{pH}$ modulates the GABA concentration-response relationships. For $\alpha 1 \beta 1(A)$ and $\alpha 1 \beta 2(B) \mathrm{GABA}_{\mathrm{A}}$ receptors, peak amplitude responses were measured at $\mathrm{pH} 7.4(\bigcirc)$ and $\mathrm{pH} 5.4(\boldsymbol{\square})$ and were normalized to the responses induced by $10 \mu \mathrm{M}$ GABA at $\mathrm{pH} 7.4$ (= 1). In this and comparable figures, the curves were generated according to Equations 1 and/or 2, presented in Materials and Methods. All points in this and comparable figures represent the mean \pm SEM from $n=3-5$ cells. The insets illustrate sample GABA-activated currents induced by 10 $\mu \mathrm{M}$ GABA applied for the duration of the solid line at the indicated external pH. Calibration: $200 \mathrm{pA}, 2 \mathrm{sec}$.

\section{RESULTS}

\section{External $\mathrm{pH}$ and recombinant $\alpha \mathbf{1} \boldsymbol{\mathrm { i }}$ GABA $\mathrm{A}_{\mathrm{A}}$ receptors}

To assess whether the identity of the $\beta$ i subunit was important for the $\mathrm{pH}$-induced regulation of $\mathrm{GABA}_{\mathrm{A}}$ receptor function, recombinant $\mathrm{GABA}_{\mathrm{A}}$ receptors composed of $\alpha 1 \beta 1$ and $\alpha 1 \beta 2$ were expressed in HEK cells and used to construct full GABA concentration-response curves at normal physiological pH 7.4 and after a pH excursion to 5.4 (Fig. 1). For either construct, increasing the total $\mathrm{H}^{+}$concentration by 100 -fold resulted in potentiated responses to GABA and an increased maxima for the concentration-response curves $(p<0.05$ for the range of $5 \mu \mathrm{M}$ to $1 \mathrm{mM}$ GABA). The GABA EC ${ }_{50} \mathrm{~s}$ for $\alpha 1 \beta 1(\mathrm{pH} 7.4,5.0 \pm 0.7 \mu \mathrm{M} ; \mathrm{pH}$ $5.4,3.3 \pm 0.6 \mu \mathrm{M} ; n=3-5)$ and $\alpha 1 \beta 2(\mathrm{pH} 7.4,3.2 \pm 0.4 \mu \mathrm{M} ; \mathrm{pH}$ 5.4, $4.9 \pm 0.7 \mu \mathrm{M} ; n=3-5)$ displayed no significant change, suggesting that GABA potency was primarily unaffected by the change in external $\mathrm{pH}$ (Fig. $1 A, B)$. A direct comparison between the concentration-response curves for the two $\mathrm{GABA}_{\mathrm{A}}$ receptor heteromers indicated that $\mathrm{H}^{+}$induced a slightly larger potentiation of GABA-activated responses on $\alpha 1 \beta 1$ receptors compared with $\alpha 1 \beta 2$ receptors for $10 \mu \mathrm{M}$ GABA-activated responses (potentiated by $197.6 \pm 37.5$ and $120.1 \pm 15.5 \%$, respectively; $n=$ 5-7). An additional distinction between $\alpha 1 \beta 1$ and $\alpha 1 \beta 2 \mathrm{GABA}_{\mathrm{A}}$ receptors was that at high GABA concentrations $(>100 \mu \mathrm{M})$ in $\mathrm{pH} 5.4$, the peak of the GABA concentration-response curve was depressed only for the $\alpha 1 \beta 1$ receptors, possibly indicative of inhibition or increased desensitization. Overall, these data suggested that the identity of the $\beta$ subunit in $\alpha 1 \beta$ i constructs, although partially influential, did not have a major effect on the extent and type of modulation by $\mathrm{H}^{+}$.

\section{Identifying the residues underlying $\mathrm{H}^{+}$modulation of $\alpha 1 \beta$ i GABA $A_{A}$ receptors}

To establish the residue(s) that is important for the $\mathrm{H}^{+}$modulation of $\alpha 1 \beta \mathrm{i} \mathrm{GABA}_{\mathrm{A}}$ receptors, we titrated the $\mathrm{H}^{+}$-induced potentiation for $\alpha 1 \beta 1$ and $\alpha 1 \beta 2 \mathrm{GABA}_{\mathrm{A}}$ receptors against the external Krebs' $\mathrm{pH}$; this yielded $\mathrm{p}_{\mathrm{Ka}} \mathrm{s}$ of $6.73 \pm 0.09$ and $6.91 \pm$ 


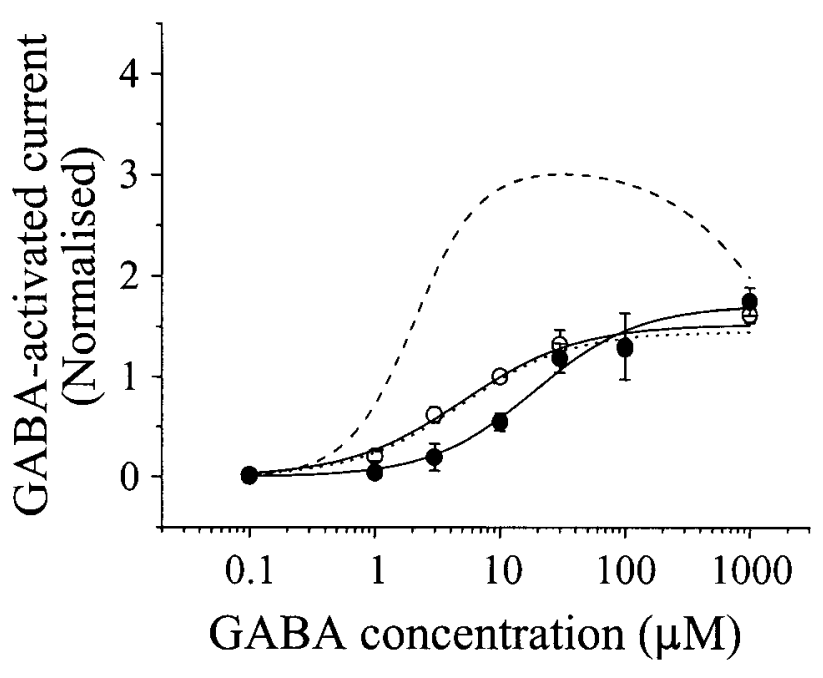

Figure 2. Modification of histidine residues by DEPC prevents protoninduced modulation of $\alpha 1 \beta 1 \mathrm{GABA}_{\mathrm{A}}$ receptors. Normalized GABA concentration-response relationships obtained at $\mathrm{pH} 7.4(\bigcirc)$ and $\mathrm{pH} 5.4$ (๑) after exposure to DEPC (1 mM) are shown. For comparison, the GABA concentration-response curves at $\mathrm{pH} 7.4$ (dotted line) and $\mathrm{pH} 5.4$ (dashed line) were taken from Figure 1A. Data are from $n=3-5$ cells.

0.13 , respectively $(n=5)$. We therefore deduced that histidines $\left(\mathrm{p}_{\mathrm{Ka}} 6\right)$ are the most likely candidates to be involved in proton modulation of $\mathrm{GABA}_{\mathrm{A}}$ receptors. Although cysteine residues also have a comparable $\mathrm{p}_{\mathrm{Ka}}(\sim 8)$ they were considered unlikely to be involved, considering that the only two external cysteine residues, located within the $\mathrm{N}$ terminal, are postulated to form a disulfide bridge (Barnard et al., 1987; Pan et al., 1995, 2000; Amato et al., 1999), precluding their involvement with $\mathrm{H}^{+}$induced modulation.

To investigate a potential role for histidine residues in $\mathrm{H}^{+}$ regulation of $\mathrm{GABA}_{\mathrm{A}}$ receptor function, we used DEPC, a reagent that irreversibly converts neutral imidazole groups into $N$-carbethoxyhistidyl derivatives (Miles, 1977). HEK cells expressing $\alpha 1 \beta \mathrm{i}$ subunit constructs were exposed to $1 \mathrm{mM}$ DEPC at $\mathrm{pH}$ 7.4. A brief application (4 min) of DEPC to $\alpha 1 \beta$ i receptors irreversibly abolished the potentiation of GABA-activated responses observed at pH 5.4 in the absence of DEPC. Inspection of GABA concentration-response curves revealed that after DEPC treatment, lowering the external $\mathrm{pH}$ to 5.4 induced a small lateral shift in the GABA concentration-response relationship, causing a reduction in the potency of GABA $\left(\mathrm{EC}_{50} \mathrm{~s}\right.$ for $\alpha 1 \beta 1$ : $\mathrm{pH} 7.4$, $5.1 \pm 1.3 \mu \mathrm{M} ; \mathrm{pH} 5.4,18.8 \pm 4.6 \mu \mathrm{M} ; p<0.05$ ) (Fig. 2). These data were in accord with one or more histidines underlying the $\mathrm{H}^{+}$induced potentiation of GABA-activated responses, and this effect appeared to be masking a weak inhibitory action of $\mathrm{H}^{+}$that was clearly manifest only when the histidines had been covalently modified.

\section{Site-specific mutagenesis of external histidines on $\alpha \mathbf{1} \boldsymbol{\beta}$ i receptors}

Considering the ablation of $\mathrm{H}^{+}$modulation by DEPC, the exact molecular determinants of this potentiation were sought using site-specific mutagenesis. The $\alpha 1 \beta$ i heteromers possess numerous external histidine residues, eight on the $\alpha 1$ subunit and four on the $\beta \mathrm{i}$ subunits. External residues were selected because internal $\mathrm{pH}$ changes have little effect on $\mathrm{GABA}_{\mathrm{A}}$ receptor function (Krishek et al., 1996). The $\beta$ subunit was examined primarily because of the pivotal role this subunit family plays in the expres-

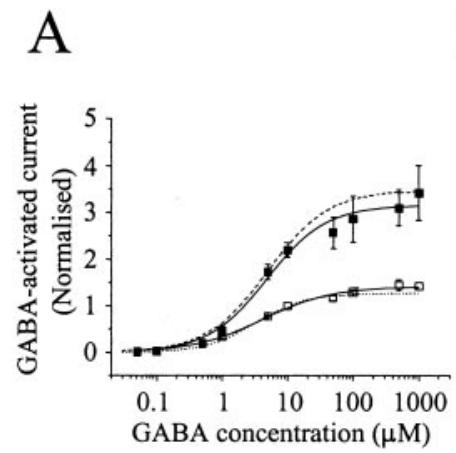

B

Figure 3. Mutating histidines 107 or 119 in the $\beta 2$ subunit do not alter proton-induced modulation of $\alpha 1 \beta 2 \mathrm{GABA}_{\mathrm{A}}$ receptors. Normalized GABA concentration-response relationships for $\alpha 1 \beta 2^{\mathrm{H} 107 \mathrm{~A}}(A)$ and $\alpha 1 \beta 2^{\mathrm{H} 119 \mathrm{~A}}(B)$ at $\mathrm{pH} 7.4(\square)$ and $\mathrm{pH} 5.4$ (回. The comparative concentration-response curves for the wild-type $\alpha 1 \beta 2$ receptor at $\mathrm{pH} 7.4$ (dotted line) and $\mathrm{pH} 5.4$ (dashed line) were taken from Figure $1 B$. Data are from $n=3-5$ cells.

sion and function of $\mathrm{GABA}_{\mathrm{A}}$ receptors (Connolly et al., 1996). The number of histidines considered to be potentially involved in the $\mathrm{H}^{+}$modulation on the $\beta$ subunit was reduced to three by including only those that are conserved between all $\beta$ subunits, because $\mathrm{H}^{+}$modulation of $\mathrm{GABA}_{\mathrm{A}}$ receptor function is not critically dependent on the identity of the $\beta$ subunit. The three candidate histidines on the $\beta 2$ subunit were H107 and H119, located in the $\mathrm{N}$ terminal, and $\mathrm{H} 267$, located in TM2, the ion channel domain. Each histidine in the $\beta 2$ subunit was sequentially substituted, initially to alanine, and coexpressed with wild-type $\alpha 1$ subunits in HEK cells.

Neither the mutant $\alpha 1 \beta 2^{\mathrm{H} 107 \mathrm{~A}}$ nor $\alpha 1 \beta 2^{\mathrm{H} 119 \mathrm{~A}} \mathrm{GABA}_{\mathrm{A}}$ receptors differed in their response to changing the external $\mathrm{pH}$ to 5.4, which still potentiated responses to GABA to levels similar to those observed with the wild-type $\alpha 1 \beta 2$ receptors $\left(\mathrm{EC}_{50} \mathrm{~S}\right.$ : $\alpha 1 \beta 2^{\text {H107A }}$ pH 7.4, $4.1 \pm 0.6 \mu \mathrm{M} ; \mathrm{pH} 5.4,4.8 \pm 0.9 \mu \mathrm{M}$; $\left.\alpha 1 \beta 2^{\mathrm{H} 119 \mathrm{~A}}: \mathrm{pH} 7.4,3.0 \pm 0.4 \mu \mathrm{M} ; \mathrm{pH} 5.4,4.9 \pm 0.5 \mu \mathrm{M} ; p>0.05\right)$, compared with $\alpha 1 \beta 2$ wild type for both mutants (Fig. $3 A, B$ ). However, substituting $\mathrm{H} 267$ with alanine, previously identified to play a major role in $\mathrm{Zn}^{2+}$ inhibition of GABA-activated responses (Wooltorton et al., 1997a; Horenstein and Akabas, 1998) on $\alpha 1 \beta$ i receptors, ablated the potentiating effect of $\mathrm{H}^{+}$(Fig. 4). Although the GABA concentration-response curve for the mutant $\alpha 1 \beta 1^{\mathrm{H} 267 \mathrm{~A}}$ did not exhibit an enhanced maximum response at $\mathrm{pH} 5.4$, it was evident for both $\alpha 1 \beta 1^{\mathrm{H} 267 \mathrm{~A}}$ and $\alpha 1 \beta 2^{\mathrm{H} 267 \mathrm{~A}}$ receptors that low $\mathrm{pH}$ caused a small reduction in GABA potency $\left(\mathrm{EC}_{50} \mathrm{~s}\right.$ for $\alpha 1 \beta 2^{\mathrm{H} 267 \mathrm{~A}}$ : $\mathrm{pH} 7.4,3.2 \pm 0.4 \mu \mathrm{M}$; pH 5.4, $7.1 \pm 1.9 \mu \mathrm{M}$; $p>0.05$ ) (Fig. 4). This weak inhibitory effect of $\mathrm{H}^{+}$was manifest between GABA concentrations of 1 and $30 \mu \mathrm{M}$ and appeared analogous to the effect of DEPC on the GABA concentrationresponse curve for the wild-type $\alpha 1 \beta 1$ (Fig. 2) or $\alpha 1 \beta 2$ receptors.

The lack of any potentiating effect of $\mathrm{H}^{+}$on the $\mathrm{GABA}_{\mathrm{A}}$ receptor incorporating the mutant $\mathrm{H} 267 \mathrm{~A}$ suggested that this histidine residue may form a key protonation site for $\mathrm{H}^{+}$ions and is likely to be the only histidine involved. This latter point was reassessed by exposing $\alpha 1 \beta 1^{\mathrm{H} 267 \mathrm{~A}} \mathrm{GABA}_{\mathrm{A}}$ receptors to $1 \mathrm{~mm}$ DEPC. This modifying agent did not further affect the GABA concentration-response curves, nor did it affect the weak inhibitory effect revealed once the $\mathrm{H}^{+}$-induced potentiating effect had been abolished (data not shown). 


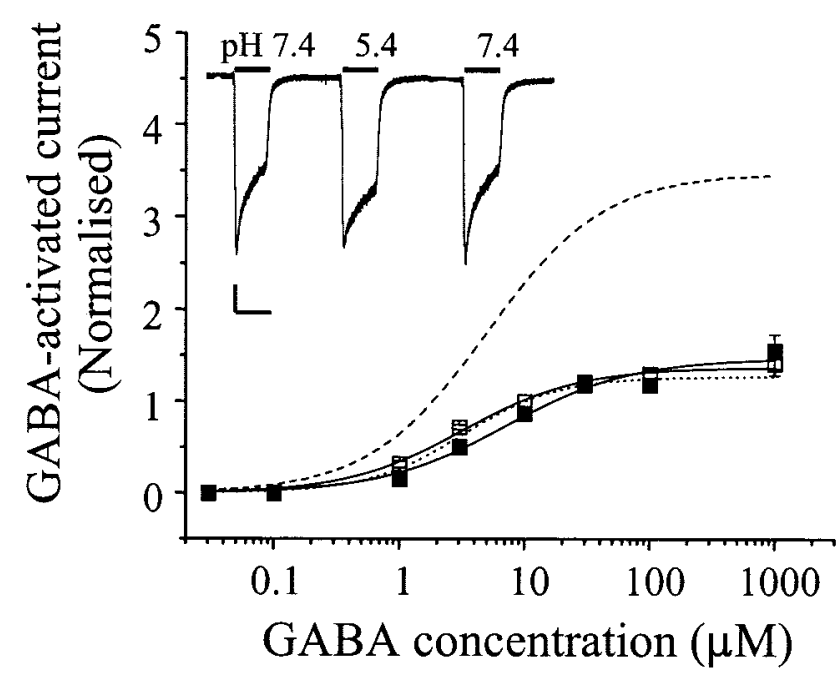

Figure 4. Mutation of the TM2 histidine 267 in the $\beta 2$ subunit ablates proton sensitivity of $\alpha 1 \beta 2 \mathrm{GABA}_{\mathrm{A}}$ receptors. A normalized GABA concentration-response relationship for $\alpha 1 \beta 2^{\mathrm{H} 267 \mathrm{~A}} \mathrm{GABA}_{\mathrm{A}}$ receptors at $\mathrm{pH} 7.4(\square)$ and $\mathrm{pH} 5.4$ (ם) is shown, including the comparison with the curve fits for $\alpha 1 \beta 2$ receptors at $\mathrm{pH} 7.4$ (dotted line) and $\mathrm{pH} 5.4$ (dashed line). The inset demonstrates typical responses to $10 \mu \mathrm{M}$ GABA recorded at pH 7.4 and $\mathrm{pH} 5.4$ for $\alpha 1 \beta 2^{\mathrm{H} 267 \mathrm{~A}}$ receptors. Calibration: $200 \mathrm{pA}, 2 \mathrm{sec}$.

\section{Charged mutations at $\mathrm{H} 267$ in the $\beta$ subunit}

To further investigate whether $\mathrm{H}^{+}$could be binding to $\mathrm{H} 267$, the residue that also has a pivotal role in $\mathrm{Zn}^{2+}$ inhibition, two additional substitutions were made in the $\beta 2$ subunit for subsequent coexpression with wild-type $\alpha 1$ subunits. These substitutions introduced amino acids with charged side chains: glutamate (E, negative) and lysine (K, positive) at position H267. Glutamate was selected because it has a projected $\mathrm{p}_{\mathrm{Ka}}$ for the side chain carboxyl group of $\leq 4$ and probably less in the $\mathrm{GABA}_{\mathrm{A}}$ receptor protein and would not be protonated at $\mathrm{pH} 7.4$ (100\% anionic) and only minimally at $\mathrm{pH} 5.4$ ( $96.2 \%$ anionic). Thus, we predict that $\mathrm{H}^{+}$will be ineffective at potentiating GABA-activated responses if they do indeed bind to $\mathrm{H} 267$. However, for $\mathrm{Zn}^{2+}$ inhibition, the ability of the glutamate carboxyl group to act as an electron donor suggests that it will be capable of binding $\mathrm{Zn}^{2+}$, a role that it fulfills in $\mathrm{Zn}^{2+}$-containing metalloenzymes (Vallee and Auld, 1990). Thus, if $\mathrm{Zn}^{2+}$ binds to H267, we would expect the retention of some inhibitory activity at the mutant $\alpha 1 \beta 2^{\mathrm{H} 267 \mathrm{E}}$ receptor but possibly at a reduced level compared with the wildtype receptor containing $\beta 2^{\mathrm{H} 267}$.

Exposure of $\alpha 1 \beta 2^{\mathrm{H} 267 \mathrm{E}}$ receptors to low external $\mathrm{pH} 5.4$ abolished the effect of $\mathrm{H}^{+}$on GABA-activated responses, as predicted if this residue forms a site for protonation $\left(\mathrm{EC}_{50}: \mathrm{pH} 7.4\right.$, $3.4 \pm 0.5 \mu \mathrm{M} ; \mathrm{pH} 5.4,4.8 \pm 1 \mu \mathrm{M} ; p>0.05$ compared with $\alpha 1 \beta 2$ wild type) (Fig. 5A). However, the level of $\mathrm{Zn}^{2+}$ inhibition over the concentration range of $1 \mu \mathrm{M}$ to $10 \mathrm{mM}$ for the $\beta 2^{\mathrm{H} 267 \mathrm{E}}$ substitution was less than expected (Fig. 6). The mutation disrupted antagonism, but the $\mathrm{Zn}^{2+} \mathrm{IC}_{50}$ was $30.6 \pm 7.3 \mu \mathrm{M}$, almost identical to that determined previously for $\mathrm{GABA}_{\mathrm{A}}$ receptors incorporating the mutation $\beta \mathrm{i}^{\mathrm{H} 267 \mathrm{~A}}$ (Wooltorton et al., 1997a) but greater than that for the $\alpha 1 \beta 2$ wild type $\left(\mathrm{IC}_{50}: 0.65 \pm 0.03\right.$ $\mu \mathrm{M} ; n=4$ ) (Fig. 6).

The lysine substitution at position 267 was performed because the side chain, with a projected $\mathrm{p}_{\mathrm{Ka}}$ of 10 , is positively charged at $\mathrm{pH} 7.4$ (99.7\% cationic) and also at $\mathrm{pH} 5.4(100 \%)$. Therefore, this residue would already be protonated and could not partici-

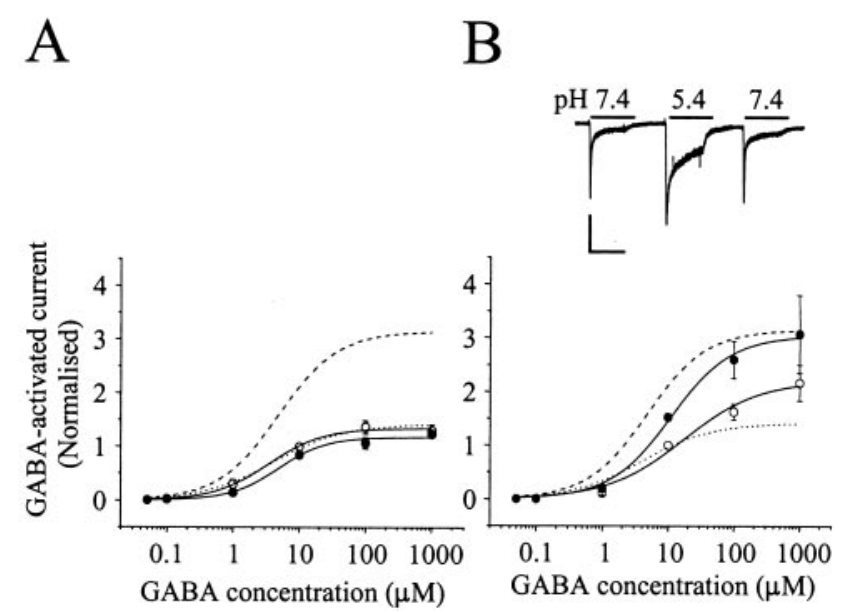

Figure 5. Effect of charged mutations at position $\mathrm{H} 267$ in the $\beta$ subunit on $\alpha 1 \beta 2 \mathrm{GABA}_{\mathrm{A}}$ receptor sensitivity to protons. Normalized GABA concentration-response relationships for $\alpha 1 \beta 2^{\mathrm{H} 267 \mathrm{E}}(A)$ and $\alpha 1 \beta 2^{\mathrm{H} 267 \mathrm{~K}}$ $(B) \mathrm{GABA}_{\mathrm{A}}$ receptors at $\mathrm{pH} 7.4(\bigcirc)$ and $\mathrm{pH} 5.4(\bullet)$ are shown, together with curve fits for the $\alpha 1 \beta 2$ wild-type receptor at $\mathrm{pH} 7.4$ (dotted line) and pH 5.4 (dashed line). Data are from $n=3-5$ cells. The inset illustrates 10 $\mu \mathrm{M}$ GABA-activated currents at $\mathrm{pH} 7.4$ and $\mathrm{pH} 5.4$ obtained from $\alpha 1 \beta 2^{\mathrm{H} 267 \mathrm{~K}}$ receptors. Note the increased rate and extent of receptor desensitization. Calibration: $400 \mathrm{pA}, 2 \mathrm{sec}$.

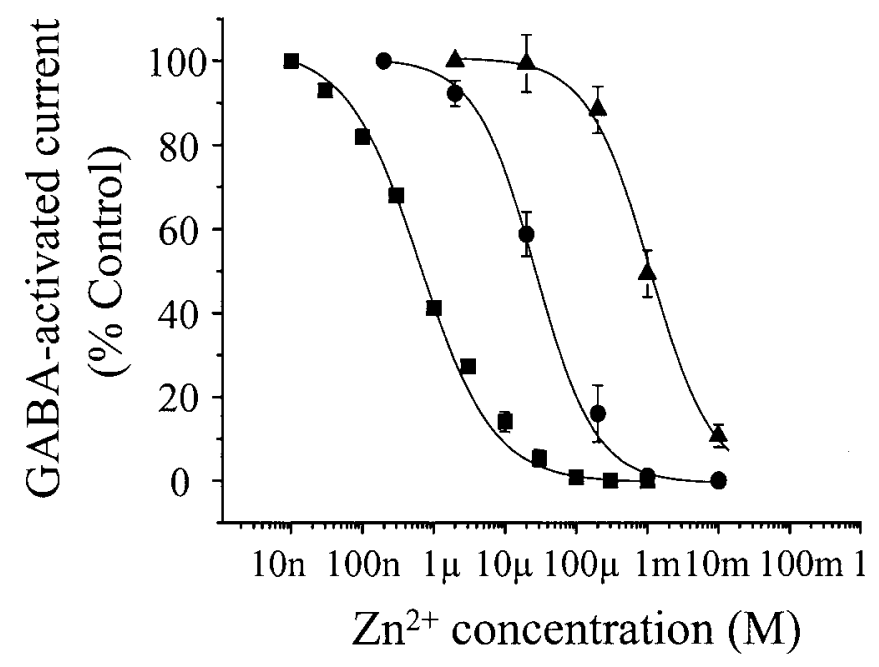

Figure 6. $\quad \mathrm{Zn}^{2+}$ concentration inhibition curves for $\alpha 1 \beta 2(\mathbf{\square}), \alpha 1 \beta 2^{\mathrm{H} 267 \mathrm{E}}$ $(\bullet)$, and $\alpha 1 \beta 2^{\mathrm{H} 267 \mathrm{~K}}(\boldsymbol{\Delta})$ receptors determined by coapplication of $\mathrm{Zn}^{2+}$ with $10 \mu \mathrm{M}$ GABA. The ordinate describes the response amplitude to GABA in $\mathrm{Zn}^{2+}$ as a percentage of the control response to GABA in the absence of $\mathrm{Zn}^{2+}$. After each $\mathrm{Zn}^{2+}$ application, full recoveries from inhibition were obtained. The data were obtained from $n=3-5$ cells and were fitted using Equation 3, presented in Materials and Methods.

pate in the modulation of GABA-activated currents between $\mathrm{pH}$ 5.4 and $\mathrm{pH}$ 7.4. In addition, $\mathrm{Zn}^{2+}$ inhibition should be markedly reduced, as observed with the $\beta 2^{\mathrm{H} 267 \mathrm{~A}}$ substitution. However, the charged side chain presented by the lysine residue conferred unusual and profoundly different functional properties on the $\mathrm{GABA}_{\mathrm{A}}$ receptor. First, this mutation did not ablate the $\mathrm{H}^{+}$ sensitivity of $10 \mu \mathrm{M}$ GABA-activated currents, with potentiation by $52 \pm 7 \%$ observed at $\mathrm{pH} 5.4$ compared with $\mathrm{pH} 7.4\left(\mathrm{EC}_{50}\right.$ : $\mathrm{pH}$ 7.4, $17.2 \pm 7.4 \mu \mathrm{M} ; \mathrm{pH} 5.4,11 \pm 1.9 \mu \mathrm{M} ; p<0.05$ compared with $\alpha 1 \beta 2$ wild type; $n=5$ ) (Fig. $5 B$ ). Second, the lysine mutation further reduced the sensitivity to $\mathrm{Zn}^{2+}$, with the inhibition curve then defined by an $\mathrm{IC}_{50}$ of $990 \pm 116 \mu \mathrm{M}$ (Fig. 6). Finally, the 
desensitization profile of the GABA-induced currents for $\alpha 1 \beta 2^{\mathrm{H} 267 \mathrm{~K}}$ receptors was markedly affected, with increased rates of desensitization and peak currents declining back to the baseline holding current, even during GABA application (Fig. 5B, inset). These results clearly emphasized the crucial nature of the identity of the residue at position 267 in the ion channel lining of the $\beta$ subunit in shaping the response profile of the $\mathrm{GABA}_{\mathrm{A}}$ receptor.

\section{DISCUSSION}

This study concludes that for $\alpha 1 \beta \mathrm{i} \mathrm{GABA}_{\mathrm{A}}$ receptors, $\mathrm{H}^{+}$induced potentiation completely relies on a single histidine residue, $\mathrm{H} 267$, in $\beta$ subunits; this residue resides at the external portal of the ion channel. Previous site-specific mutagenesis revealed that $\mathrm{H} 267$ also underpinned a substantial component of $\mathrm{Zn}^{2+}$ inhibition of GABA-activated responses, suggesting that it is important for the allosteric modulation of $\mathrm{GABA}_{\mathrm{A}}$ receptor function.

The involvement of a histidine residue, conserved between the $\beta$ subunit isoforms, in the regulation of $\mathrm{GABA}_{\mathrm{A}}$ receptor function was suggested from the similar $\mathrm{pH}$ titration profiles for $\alpha 1 \beta 1$ and $\alpha 1 \beta 2$ receptors. This was also supported by the unequivocal effect of DEPCs completely removing any potentiation by $\mathrm{H}^{+}$on $\alpha 1 \beta 1$ and $\alpha 1 \beta 2$ receptors. Interestingly, this action unveiled a small inhibitory effect of $\mathrm{H}^{+}$that was observed only at low $\mathrm{pH}$ values with a projected $\mathrm{p}_{\mathrm{Ka}}$ approaching 4 , indicating the involvement of aspartate and/or glutamate residues. Mutagenesis subsequently confirmed that only $\mathrm{H} 267$ in the $\beta$ subunits was critically involved in $\mathrm{H}^{+}$-induced potentiation. Because $\mathrm{H}^{+}$can compete and prevent the inhibitory effect of $\mathrm{Zn}^{2+}$ on recombinant and native $\mathrm{GABA}_{\mathrm{A}}$ receptors (Krishek et al., 1998) and because $\mathrm{H} 267$ has already been suggested to be an important coordinating residue for $\mathrm{Zn}^{2+}$ inhibition at $\alpha 1 \beta$ i subunit $\mathrm{GABA}_{\mathrm{A}}$ receptors (Wooltorton et al., 1997a; Horenstein and Akabas, 1998), we suggest that protonation of this residue is likely to underlie the potentiating effect of $\mathrm{H}^{+}$on $\alpha 1 \beta \mathrm{i} \mathrm{GABA}_{\mathrm{A}}$ receptors. Furthermore, mutating $\mathrm{H} 267$ does not affect GABA activation of the receptor, thus suggesting that this residue is not part of the main agonist signal transduction process.

To further examine the role of $\mathrm{H} 267$, we substituted this histidine for glutamate and lysine to vary the charge in the side chain. Although inclusion of the carboxyl side chain for $\alpha 1 \beta 2^{\mathrm{H} 267 \mathrm{E}}$ abolished $\mathrm{H}^{+}$-induced potentiation, $\mathrm{Zn}^{2+}$ inhibition was reduced to an extent similar to that observed after alanine substitution. This suggested that the orientation of the side chain in this position must be important, because glutamate, by virtue of electron donation, would be expected to bind $\mathrm{Zn}^{2+}$ and thus substitute, at least partly, for histidine. However, it is clear that this did not occur. The lysine substitution, however, yielded unexpected results, with the $\mathrm{H}^{+}$-induced potentiation only partly reduced when we might have expected abolition; however, the level of $\mathrm{Zn}^{2+}$ inhibition was markedly reduced, far more than expected from the results with the neutral alanine substitution at position 267. We had predicted that the $\mathrm{H}^{+}$-induced potentiation would be ablated because of the positively charged lysine side chain $\left(\mathrm{p}_{\mathrm{Ka}} 10\right)$; however, if $\mathrm{H}^{+}$is protonating the lysine residue at position 267 , this residue cannot be $100 \%$ charged, and the $\mathrm{p}_{\mathrm{Ka}}$ must be reduced by at least 2000 - to 3000 -fold (2-3 pH units) to $\sim 7$ for this to occur. Such a shift in $\mathrm{p}_{\mathrm{Ka}}$ has been reported in the inward rectifier potassium channel, $\mathrm{K}_{\mathrm{ir}} 1.1$, where an intracellular pH-sensitive lysine can be protonated at pH 5.4 (Schulte et al., 1999). Such an effect can be achieved only if other positively charged residues (e.g., arginines and lysines) electrostatically shield the proton-sensitive lysine from basal $\mathrm{H}^{+}$(Schulte et al., 1999). Indeed, both R269 and K274 (conserved throughout the $\mathrm{GABA}_{\mathrm{A}}$ receptor $\alpha, \beta$, and $\gamma$ subunit families) lie close, at least in primary sequence order, to $\mathrm{H} 267 \mathrm{~K}$. In the $\beta$ subunits, such proximity might act to shield the lysine at 267 from $\mathrm{H}^{+}$. The results with $\mathrm{Zn}^{2+}$ and $\mathrm{H} 267 \mathrm{~K}$ could be explained by the action this residue has in further disrupting, beyond that achieved with $\mathrm{H} 267 \mathrm{~A}$, the allosteric mechanism for $\mathrm{Zn}^{2+}$ inhibition.

Although mutagenesis cannot unequivocally indicate the presence of a binding site on a receptor, the lack of any relatively comparable effects on $\mathrm{H}^{+}$and $\mathrm{Zn}^{2+}$ modulation by E267 and K267 suggests that this position is probably not involved in a common signal transduction pathway that is "downstream" of ion binding sites. Furthermore, because $\mathrm{H}^{+}$and $\mathrm{Zn}^{2+}$ have opposite effects on $\mathrm{GABA}_{\mathrm{A}}$ receptor function, it is also unlikely that $\mathrm{H} 267$ is an element in part of a common signal transduction mechanism.

The identification of $\mathrm{H} 267$ as a potential binding site for $\mathrm{H}^{+}$ and $\mathrm{Zn}^{2+}$ presented a curious problem. If these positively charged ions are capable of binding to the same residue, how can they induce completely opposite effects of inhibition $\left(\mathrm{Zn}^{2+}\right)$ and potentiation $\left(\mathrm{H}^{+}\right)$on $\mathrm{GABA}_{\mathrm{A}}$ receptor function? The key to this question may involve the different ways in which $\mathrm{H}^{+}$and $\mathrm{Zn}^{2+}$ interact with the imidazole groups of histidines. The addition of $\mathrm{H}^{+}$will cause protonation of individual imidazole rings, independent of any other residues. This protonation and subsequent potentiation of the GABA response might involve electrostatic repulsion between adjacent imidazole groups on the $\beta$ subunits in the channel (two to three depending on subunit stoichiometry), causing a local conformational change in the receptor. In contrast, zinc ions will form a coordinated bond with one of the imidazole ring nitrogens and at least three other residues (which could include other imidazole rings from additional $\beta$ subunits in the receptor) and an activated water molecule. This would be typical of many $\mathrm{Zn}^{2+}$ binding sites in metalloenzymes (Vallee and Auld, 1990). The coordination of $\mathrm{Zn}^{2+}$ with $\mathrm{H} 267$ would inhibit receptor function allosterically rather than by a physical channel block mechanism (Legendre and Westbrook, 1991; Smart, 1992; Gingrich and Burkat, 1998). This coordination, compared with protonation, would not polarize adjacent imidazole rings. Thus, mechanistically, at the level of amino acid side chains, it is conceivable that $\mathrm{H}^{+}$and $\mathrm{Zn}^{2+}$ could cause differential effects on channel function, but the precise movements of amino acids will need to await x-ray crystallographic study. A similar scenario accounts for the differential effects of $\mathrm{Zn}^{2+}$ and $\mathrm{H}^{+}$on the M2 ion channel from influenza A virus (Okada et al., 2001).

Overall, these data indicate the importance of a single TM2 residue in the ion channel lining of the $\beta$ subunits for $\mathrm{H}^{+}$-induced modulation of $\mathrm{GABA}_{\mathrm{A}}$ receptor function and also suggest that $\mathrm{H} 267$ could be a potential binding site for at least two types of cations.

\section{REFERENCES}

Amato A, Connolly CN, Moss SJ, Smart TG (1999) Modulation of neuronal and recombinant $\mathrm{GABA}_{\mathrm{A}}$ receptors by redox reagents. J Physiol (Lond) 517:35-50.

Barnard EA, Darlison MG, Seeburg P (1987) Molecular biology of $\mathrm{GABA}_{\mathrm{A}}$ receptor: the receptor/channel superfamily. Trends Neurosci 10:502-509.

Connolly CN, Krishek BJ, McDonald BJ, Smart TG, Moss SJ (1996) Assembly and cell surface expression of heteromeric and homomeric gamma-aminobutyric acid type A receptors. J Biol Chem 271:89-96. Horenstein J, Akabas MH (1998) Location of a high affinity $\mathrm{Zn}^{2+}$ 
binding site in the channel of $\alpha 1 \beta 1 \gamma$-aminobutyric acid receptors. Mol Pharmacol 53:870-877.

Huang RQ, Dillon GH (1999) Effect of extracellular pH on GABAactivated current in rat recombinant receptors and thin hypothalamic slices. J Neurophysiol 82:1233-1243.

Gingrich KJ, Burkat PM (1998) $\mathrm{Zn}^{2+}$ inhibition of recombinant $\mathrm{GABA}_{\mathrm{A}}$ receptors: an allosteric, state-dependent mechanism determined by the gamma-subunit. J Physiol (Lond) 506:609-625.

Kaila K (1994) Ionic basis of $\mathrm{GABA}_{\mathrm{A}}$ receptor channel function in the nervous system. Prog Neurobiol 42:489-537.

Krishek BJ, Smart TG (2001) Proton sensitivity of rat cerebellar granule cell $\mathrm{GABA}_{\mathrm{A}}$ receptors: dependence on neuronal development. J Physiol (Lond) 530:219-233.

Krishek BJ, Amato A, Connolly CN, Moss SJ, Smart TG (1996) Proton sensitivity of the $\mathrm{GABA}_{\mathrm{A}}$ receptor is associated with the receptor subunit composition. J Physiol (Lond) 492:431-443.

Krishek BJ, Moss SJ, Smart TG (1998) Interaction of $\mathrm{H}^{+}$and $\mathrm{Zn}^{2+}$ on recombinant and native rat neuronal $\mathrm{GABA}_{\mathrm{A}}$ receptors. J Physiol (Lond) 507:639-652.

Laurie DJ, Wisden W, Seeburg PH (1992) The distribution of thirteen $\mathrm{GABA}_{\mathrm{A}}$ receptor subunit mRNAs in the rat brain. III. Embryonic and postnatal development. J Neurosci 12:4151-4172.

Legendre P, Westbrook GL (1991) Noncompetitive inhibition of $\gamma$-aminobutyric acid ${ }_{\mathrm{A}}$ channels by Zn. Mol Pharmacol 39:267-274.

Mehta AK, Ticku MK (1999) An update on GABA $_{\mathrm{A}}$ receptors. Brain Res Brain Res Rev 29:196-217.

Miles EW (1977) Modification of histidyl residues in proteins by dietheylpyrocarbonate. Methods Enzymol 47:431-443.

Moss SJ, Smart TG (2001) Constructing inhibitory synapses. Nat Rev Neurosci 2:240-250.

Nayeem N, Green TP, Martin IL, Barnard EA (1994) Quaternary structure of the native $\mathrm{GABA}_{\mathrm{A}}$ receptor determined by electron microscopic image analysis. J Neurochem 62:815-818.

Okada A, Miura T, Takeuchi H (2001) Protonation of histidine and histidine-tryptophan interaction in the activation of the M2 ion channel from influenza a virus. Biochemistry 40:6053-6060.

Otis TS, Staley KJ, Mody I (1991) Perpetual inhibitory activity in mammalian brain slices generated by spontaneous GABA release. Brain Res 545:142-150.

Pan ZH, Bahring R, Grantyn R, Lipton SA (1995) Differential modulation by sulfhydryl redox agents and glutathione of GABA- and glycineevoked currents in rat retinal ganglion cells. J Neurosci 15:1384-1391.
Pan ZH, Zhang X, Lipton SA (2000) Redox modulation of recombinant human GABA(A) receptors. Neuroscience 98:333-338.

Pasternack M, Smirnov S, Kaila K (1996) Proton modulation of functionally distinct $\mathrm{GABA}_{\mathrm{A}}$ receptors in acutely isolated pyramidal neurons of rat hippocampus. Neuropharmacology 35:1279-1288.

Rabow LE, Russek SJ, Farb DH (1996) From ion currents to genomic analysis: recent advances in $\mathrm{GABA}_{\mathrm{A}}$ receptor research. Synapse 21:189-274.

Robello M, Baldelli P, Cupello A (1994) Modulation by extracellular $\mathrm{pH}$ of the activity of $\mathrm{GABA}_{\mathrm{A}}$ receptors on rat cerebellum granule cells. Neuroscience 61:833-837.

Schulte U, Hahn H, Konrad M, Jeck N, Derst C, Wild K, Weidemann S, Ruppersberg JP, Fakler B, Ludwig J (1999) pH gating of ROMK (K(ir)1.1) channels: control by an Arg-Lys-Arg triad disrupted in antenatal Bartter syndrome. Proc Natl Acad Sci USA 96:15298-15303.

Sieghart W (1995) Structure and pharmacology of $\gamma$-aminobutyric acid A $_{\mathrm{A}}$ receptor subtypes. Pharmacol Rev 47:181-234.

Smart TG (1992) A novel modulatory binding site for zinc on the GABAA receptor complex in cultured rat neurones. J Physiol (Lond) 447:587-625.

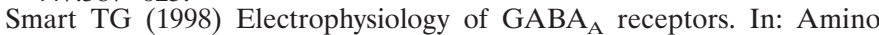
acid neurotransmission (Turner AJ, Stephenson FA, eds), pp 37-63. London: Portland.

Smart TG, Xie X, Krishek BJ (1994) Modulation of inhibitory and excitatory amino acid receptor ion channels by zinc. Prog Neurobiol 42:393-441.

Vallee BL, Auld DS (1990) Zinc coordination, function, and structure of zinc enzymes and other proteins. Biochemistry 29:5647-5659.

Wilkins ME, Harvey RJ, Smart TG (2001) Identification of the $\mathrm{H}^{+}$ modulatory site on a GABA ${ }_{\mathrm{A}}$ receptor. Br J Pharmacol 133:P166.

Wooltorton JR, McDonald BJ, Moss SJ, Smart TG (1997a) Identification of a $\mathrm{Zn}^{2+}$ binding site on the murine $\mathrm{GABA}_{\mathrm{A}}$ receptor complex: dependence on the second transmembrane domain of $\beta$ subunits. J Physiol (Lond) 505:633-640.

Wooltorton JR, Moss SJ, Smart TG (1997b) Pharmacological and physiological characterization of murine homomeric $\beta 3 \mathrm{GABA}_{\mathrm{A}}$ receptors. Eur J Neurosci 9:2225-2235.

Xiong ZQ, Stringer JL (2000) Extracellular pH responses in CA1 and the dentate gyrus during electrical stimulation, seizure discharges, and spreading depression. J Neurophysiol 83:3519-3524.

Zhai J, Peoples RW, Li C (1998) Proton inhibition of GABA-activated current in rat primary sensory neurons. Pflügers Arch 435:539-545. 